\title{
THE EIGHT HABITS OF HIGHLY EFFECTIVE COMMUNITY SOCIAL WORKERS: A SOUTH AFRICAN PERSPECTIVE
}

\section{Weyers}

\section{INTRODUCTION}

Much has changed in the 10 years since the publication of the White Paper for Social Welfare in February 1997. The boundaries of knowledge and expertise on the delivery of developmental social work services have been expanded and the general field of social development has been subjected to intense analysis and continual reconceptualisation. Perhaps the time has come for the social work fraternity to start asking what has been learnt in the past decade. It is especially pertinent to know which factors determine success and failure in developmental social work in general and community work in particular and what makes some community social workers so effective while others fail. The latter half of this question prompted a research project in which Stephen R. Covey's (1989) basic approach in determining "The 7 habits of highly effective people" was used to ascertain the equivalent habits of highly effective community social workers. The procedure that was followed and the results that were achieved will be covered in this article.

\section{RESEARCH METHODOLOGY AND ANALYSIS}

The aim of the study was to identify the habits of highly effective community social workers within the South African context. The procedure consisted of the application of elements of the constant comparative research method (Poggenpoel, 1998:338-340) in the secondary analysis of existing literature (Strydom \& Delport, 2005:319-322). It entailed the use of the critical success factors in local community work services (Weyers \& Van den Berg, 2006) as the starting criteria in the analysis of other South African "success literature" on the subject (Covey, 1989:21). The identified habits that adhered to the starting criteria were accepted as a given, while the habits that fell outside their ambit were clustered according to type. This process produced 8 core "habits of success".

The secondary analysis was limited to articles published between the beginning of 1997 (the publication date of the White Paper for Social Welfare) and the end of 2005 in the two accredited South African social work journals, viz. Social Work/Maatskaplike Werk and Social Work Practitioner-Researcher/Maatskaplikewerk-Navorser-Praktisyn. Although it could be argued that the two journals are not necessarily the most appropriate sources and that other publications (e.g. dissertations, theses and publications by government and the private sector) should also have been included, the demarcation did hold various advantages. It provided systematic, peer-reviewed information (which is often lacking in non-scientific publications) that could, in many respects, be viewed as the state of the art of current local social work knowledge. The journals would, at least, also reflect the major trends in thinking and practice that exist in South Africa today.

The preliminary analysis of the journals produces a long list of articles that had community work and/or developmental social work as one of their themes. The list then had to be whittled down to those articles that would contribute the most to answering the core research question, viz.: "What makes effective community social workers effective?" The following criteria were used for this purpose:

- The article had to deal with grassroots-level (micro and mezzo) work done by one or more community social workers. The more neutral concept of "community social worker" was used 
to refer to any social worker (including researchers/academics) who provided a service that is described in the articles as being "community work", "community development", "community based", "community support", "social/human development", "developmental social work" or "developmental welfare" in nature. The focus was on habits on the "project level" of service delivery and not on macro issues such as reforming national policy, fostering good governance and the creation of an enabling macro environment. Hence the "grassroots" demarcation.

- Articles were preferred that dealt with an actual, practical community work/developmental social work intervention (e.g. service or project) whose success/failure had been analysed empirically and whose analysis would produce data that would indicate which habits of the practitioners contributed to the success (or failure) of the endeavour. However, some papers that gave a substantive overview and reformulation of existing theory or "other people's" empirical research were also included.

- Only articles that focused directly on South Africa were selected. Those that dealt exclusively with, for example, Botswana, Africa in general, Australia, the USA or the "world in general" were, therefore, excluded.

- Articles that did not, at least, give some indication of the practitioner's underlying habits were discarded. In this regard, Covey's definition of a "habit" was used as a basis. He defines it as "the intersection of knowledge, skill, and desire" and explains that "Knowledge is the theoretical paradigm, the what to do and the why. Skill is the how to do. And desire is the motivation, the want to do... Creating a habit requires work in all three dimensions" (Covey, 1989:47).

In spite of the stringent selection criteria, the analysis still produced a total of 24 articles. A profile of these articles is provided in Table 1.

TABLE 1

THE ARTICLES THAT WERE SELECTED

\begin{tabular}{|c|c|c|c|c|}
\hline Ref. no. & Author(s) & Date & Title & Journal* \\
\hline 1 & $\begin{array}{l}\text { Badenhorst, M. \& } \\
\text { Du Preez, M.S.E. }\end{array}$ & 2004 & $\begin{array}{l}\text { Maatskaplikewerkriglyne vir die } \\
\text { fasilitering van gemeenskapsgebaseerde } \\
\text { projekbestuur. }\end{array}$ & SWP-R, 16(2):113-122. \\
\hline 2 & Gathiram, N. & 2003 & $\begin{array}{l}\text { Participation, civil society and social } \\
\text { work practice. }\end{array}$ & SW/MW, 39(1):41-47. \\
\hline 3 & $\begin{array}{l}\text { Gray, M. \& Collett } \\
\text { van Rooyen, C.A.J. }\end{array}$ & 2002 & $\begin{array}{l}\text { The strengths perspective in social } \\
\text { work: lessons from practice. }\end{array}$ & SW/MW, 38(3):193-201. \\
\hline 4 & $\begin{array}{l}\text { Green, S. \& } \\
\text { Kruger, S.P. }\end{array}$ & 2002 & $\begin{array}{l}\text { Resource and support programmes for } \\
\text { poor families in a rural residential area. }\end{array}$ & SW/MW, 38(3):253-259. \\
\hline 5 & $\begin{array}{l}\text { Green, S. \& } \\
\text { Nieman, A. }\end{array}$ & 2003 & $\begin{array}{l}\text { Social development: good practice } \\
\text { guidelines. }\end{array}$ & SW/MW, 39(2):161-181. \\
\hline 6 & Gumbi, T.A.P. & 2002 & $\begin{array}{l}\text { Community development, participation } \\
\text { and empowerment: conditions for rural } \\
\text { development in South Africa. }\end{array}$ & SWP-R, 14(3):114-135. \\
\hline 7 & $\begin{array}{l}\text { Kruger, S.P. \& } \\
\text { Schreuder, M. }\end{array}$ & 1999 & The effective utilisation of volunteers. & SW/MW, 35(4):333-342. \\
\hline 8 & Lombard, A. & 2003 & $\begin{array}{l}\text { Entrepreneurship in Africa: social work } \\
\text { challenges for human, social and } \\
\text { economic development. }\end{array}$ & SW/MW, 39(3):224-239. \\
\hline
\end{tabular}




\begin{tabular}{|c|c|c|c|c|}
\hline Ref. no. & Author(s) & Date & Title & Journal* \\
\hline 9 & Lombard, A. & 2005 & $\begin{array}{l}\text { Impact of social services on human, } \\
\text { social and economic development and } \\
\text { the promotion of human rights in South } \\
\text { Africa. }\end{array}$ & SW/MW, 41(3):209-227. \\
\hline 10 & $\begin{array}{l}\text { Lombard, A. \& Du } \\
\text { Preez, J. }\end{array}$ & 2004 & $\begin{array}{l}\text { Challenges for building partnerships in } \\
\text { social development. }\end{array}$ & SW/MW, 40(3):232-245. \\
\hline 11 & $\begin{array}{l}\text { Lombard, A. \& } \\
\text { Modise, V.M. }\end{array}$ & 2002 & $\begin{array}{l}\text { Retaining volunteers in African } \\
\text { communities with specific reference to } \\
\text { the Cancer Association of South Africa. }\end{array}$ & SW/MW, 38(1):1-14. \\
\hline 12 & $\begin{array}{l}\text { Malherbe, B.R. \& } \\
\text { Hendriks, E. }\end{array}$ & 2004 & $\begin{array}{l}\text { An investigation into the determinants } \\
\text { of job satisfaction and the improvement } \\
\text { of quality of work life of grassroots } \\
\text { social workers. }\end{array}$ & SW/MW, 40(1):25-42. \\
\hline 13 & $\begin{array}{l}\text { Mavalela, H.R., } \\
\text { Schenck, R \& } \\
\text { O’Neil, M. } \\
\end{array}$ & 2002 & $\begin{array}{l}\text { The story of "Phela O Phedise" income } \\
\text { generating project. }\end{array}$ & SWP-R, 14(1):48-66. \\
\hline 14 & $\begin{array}{l}\text { Mkhwanazi, H.F. } \\
\text { \& Triegaardt, J. }\end{array}$ & 2003 & $\begin{array}{l}\text { Reconceptualisation of social work: a } \\
\text { study in Johannesburg. }\end{array}$ & SWP-R, 15(1):48-60. \\
\hline 15 & $\begin{array}{l}\text { Naudé, C. \& } \\
\text { Terblanche, L.S. }\end{array}$ & 2004 & $\begin{array}{l}\text { Die ontwikkeling van 'n bemarking- } \\
\text { strategie vir Centurion Gemeenskaps- } \\
\text { diens. }\end{array}$ & SW/MW, 40(2):139-157. \\
\hline 16 & $\begin{array}{l}\text { Nel, H. \& } \\
\text { Roestenburg, W. }\end{array}$ & 2004 & $\begin{array}{l}\text { Assessment of a community: promoting } \\
\text { an equitable society through inclusion } \\
\text { and empowerment. }\end{array}$ & SW/MW, 40(2):113-123. \\
\hline 17 & Nel, J.B.S. & 2003 & $\begin{array}{l}\text { A Soweto community leadership } \\
\text { training programme: lessons out of } \\
\text { Africa. }\end{array}$ & SWP-R, 15(2):128-144. \\
\hline 18 & $\begin{array}{l}\text { Raniga, T. \& } \\
\text { Simpson, B. }\end{array}$ & 2002 & $\begin{array}{l}\text { Community participation: rhetoric or } \\
\text { reality? }\end{array}$ & SW/MW, 38(2):182-191. \\
\hline 19 & Reyneke, R.P. & 2004 & $\begin{array}{l}\text { Die benutting van narratiewe beginsels } \\
\text { tydens gemeenskapsontwikkeling. }\end{array}$ & SW/MW, 40(2):125-138. \\
\hline 20 & Schenck, C.J. & 2004 & $\begin{array}{l}\text { Problems rural social workers } \\
\text { experience. }\end{array}$ & SW/MW, 40(2):158-171. \\
\hline 21 & Simpson, B. & 2003 & $\begin{array}{l}\text { What do residents of informal } \\
\text { settlements think social workers should } \\
\text { do: voices from Bhambayi. }\end{array}$ & SW/MW, 39(2):149-160. \\
\hline 22 & Swart, I. & 2005 & $\begin{array}{l}\text { Mobilising faith-based organisations for } \\
\text { social development through a } \\
\text { participatory action research (PAR) } \\
\text { process. }\end{array}$ & SW/MW, 41(4):323-336. \\
\hline 23 & $\begin{array}{l}\text { Van den Berg, } \\
\text { A.M. \& Weyers, } \\
\text { M.L. }\end{array}$ & 2004 & $\begin{array}{l}\text { Die gemeenskapswerkdienste van die } \\
\text { private welsynsektor: 'n profiel met } \\
\text { implikasies. }\end{array}$ & SW/MW, 40(4):344-365. \\
\hline 24 & $\begin{array}{l}\text { Van der Berg, C., } \\
\text { Collins, K. \& } \\
\text { O'Neil, M.A. }\end{array}$ & 1999 & $\begin{array}{l}\text { Die gemeenskapswerker en } \\
\text { taalkonstruktivisme in die fase van } \\
\text { behoeftebepaling. }\end{array}$ & SW/MW, 35(2):113-123. \\
\hline
\end{tabular}

* SWP-R = Social Work Practitioner-Researcher. SW/MW = Social Work/Maatskaplike Werk 


\section{AN OVERVIEW OF THE 8 HABITS}

The 8 habits that immerged from the analysis will be clustered according to the focus of the community social worker's endeavours, instead of some or other priority rating. These focus areas are the service delivery system (Focus area 1), the appropriate processes and procedures (Focus area 2) and the consumer system (Focus area 3). It was also apparent that there were two habits that transcended the narrow ambit of the other three clusters. These were the building of partnerships and self-renewal. These habits will be classified as being part of a "cross-field" or "multi-field" focus (Focus area 4). The categories and habits, as well as the reference numbers of the articles in which they are mentioned or implied (Table 1), are contained in Table 2. The habits are formulated as dictums to which community social workers should adhere.

\section{TABLE 2}

\section{CATEGORISATION OF THE 8 HABITS OF HIGHLY EFFECTIVE COMMUNITY SOCIAL WORKERS}

\begin{tabular}{|c|c|}
\hline \multicolumn{1}{|c|}{ Categories and Habits } & $\begin{array}{c}\text { Reference number(s) of } \\
\text { articles* }\end{array}$ \\
\hline Focus area 1: The service delivery system & $12,14,20$ \\
\hline Habit 1: Gain the moral support of your employer and colleagues & $1,2,3,5,7,9,11,15,18$ \\
\hline Habit 2: Get and keep supporters involved & $3,6,13,14,21,24$ \\
\hline Habit 3: Be the best you can & \\
\hline Focus area 2: Processes and procedures & $2,3,6,9,16,18,19,21,22,23$ \\
\hline Habit 4: Activate the push of discomfort and the pull of hope & $1,13,17$ \\
\hline Habit 5: Use administration and planning as empowerment tools & \\
\hline Focus area 3: The consumer system & $2,3,4,5,6,8,9,13,18,19,21$ \\
\hline $\begin{array}{l}\text { Habit 6: Instil an internal locus of control in your community } \\
\text { group }\end{array}$ & 10,23 \\
\hline Focus area 4: Critical "cross-field" habits & 12,14 \\
\hline Habit 7: Build partnerships & \\
\hline Habit 8: Spend time on self-renewal & \\
\hline
\end{tabular}

*Only examples of articles are provided. The list should not be viewed as all-inclusive.

The concept of "habits" is not new to social workers, albeit that they are usually seen as negative in nature. One can even go so far as to say that community social workers and social workers in general are in the "habit replacement business", viz. "breaking the bad habits" of individuals, families, groups, communities and even countries and the "instilling" of some type of "good habits" in their stead. Although habits can be learned and unlearned, it involves tremendous commitment to break deeply imbedded habitual tendencies and to replace them with others (Covey, 1989:46). It requires new knowledge, new skills and especially the desire for change. Once change has been achieved, it also requires commitment not to fall back "on the old ways" of being and doing.

The "habit replacement business" does not, however, only apply to the "people out there". Community social workers also have habits, bad and good, that need replacement and entrenchment. It would be especially helpful in this process if practitioners knew which habits would make them more effective and would bring the maximum long-term beneficial results in 
their professional endeavours. A profile of such "habits of effectiveness" would have the additional advantage of providing a set of criteria against which current habits could be judged and inappropriate (i.e. "bad") ones identified.

The analysis of the journal articles brought a slew of habits, big and small, to the fore. The result of their categorisation is also implied in the "Model of the 8 habits of highly effective community social workers" as contained in Diagram 1.

\section{DIAGRAM 1 \\ A MODEL OF THE 8 HABITS OF HIGHLY EFFECTIVE COMMUNITY SOCIAL WORKERS}

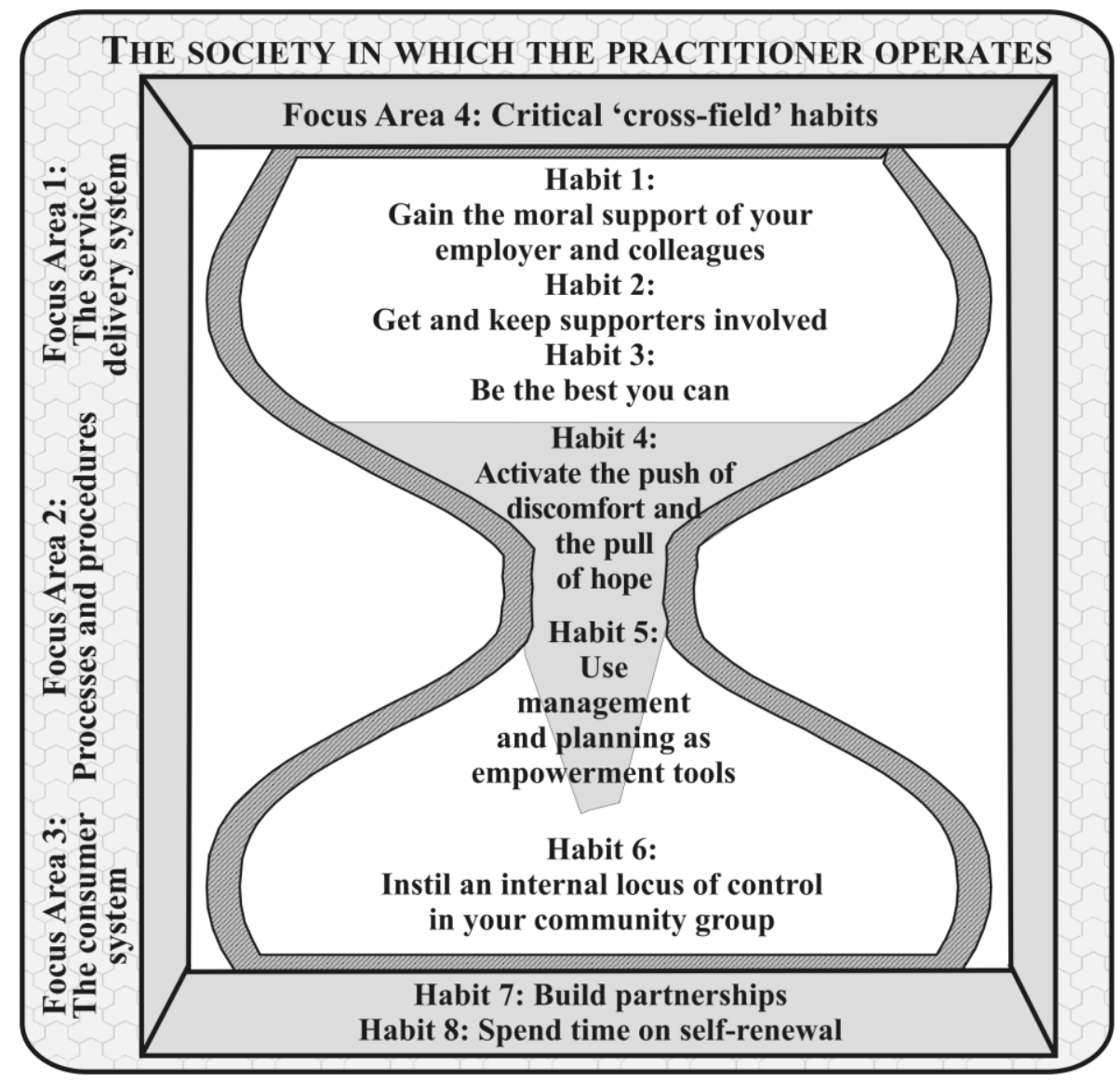

The hourglass was chosen as the main metaphor for the model, because it illustrates two inherent characteristics of the habits of effectiveness. The first is that they are part of a bidirectional process. Therefore, habits that focus on the service delivery system will influence the choice of processes/procedures which, in turn, will determine the habits in dealing with the consumer system and vice versa. As in the case of an hourglass, therefore, the habits can be viewed from either top down or bottom up and still remain part of one, integrated and definable whole. The hourglass, secondly, symbolises the time factor that is ever-present in the development and living out of habits (Covey, 1989:48-49). 
Only the main characteristics of each of the 8 habits that emerged from the different articles will be discussed. It should be noted that these habits go beyond the normal/generic requirements for good practice. For example, doing sound planning and administration are prerequisites for all successful service delivery, but the additional habit of also using these processes as an employment tool (Table 2: Habit 5) would set the highly effective community social worker apart from the rest. The generic requirements for good practice will not be covered in this paper.

\section{FOCUS AREA 1: THE SERVICE DELIVERY SYSTEM}

For the purposes of the research, the service delivery system was seen as all the subsystems that made the delivery of a community work or developmental social work service possible. It especially included the community social worker, his/her employer organisation and the systems that make resources available to both (Weyers, 2001:68-73).

\section{Habit 1: Gain the moral support of your employer and colleagues}

The first habit is based on the principle that a community social worker will not be able to start or to sustain a project/service without adequate support from his/her employer organisation and the other employees of that organisation. It would seem as though successful practitioners are those who are in the habit of first gaining the moral support of their employer and colleagues before seeking support from other sources.

The acquiring of the management's approval of plans and their provision of adequate financial and or other substantive resources (e.g. facilities, transport services or infrastructure) can be viewed as a basic prerequisite for any new service (Weyers \& Van den Berg, 2006:184). What sets effective community social workers apart from the rest is their habit of also seeking and attaining the organisation system's moral support. This includes:

- convincing the organisation to accord a high priority ranking to their particular project/service;

- getting management personally involvement in the project/service (e.g. by attending meetings);

- gaining such trust from the organisation that they will provide him/her with the scope to be creative, the freedom to assert autonomy and the opportunity to take calculated risks;

- $\quad$ obtaining emotional support from his/her supervisor;

- $\quad$ acquiring adequate inputs, cooperation, support and loyalty from colleagues and office staff (Malherbe \& Hendriks, 2004:32; Mkhwanazi \& Triegaardt, 2003:56; Schenk, 2004:168; Weyers \& Van den Berg, 2006:184).

\section{Habit 2: Get and keep supporters involved}

A number of articles indicated that community work/developmental social work services do not function in a vacuum, but that they are usually highly dependent on the inputs of a wide range of supporters. The analysis showed that such supporters or "external role-players" could be grouped into four very broad categories, viz. the "support community", the so-called "resources", "fulltime" volunteers and community leaders.

Weyers and Van den Berg (2006:180) describes the support community as the more affluent individuals, groups and (especially faith-based and civic) organisations from outside the target community who are willing to make a direct contribution to the project/service without gaining any direct benefit from it. They usually became involved on a more ad hoc or short-term basis by 
delivering specialised services (e.g. entrepreneurial skills training), by providing material assistance (e.g. the donation of money or goods, the sponsoring of individuals or events and even purchasing the products of income-generating projects) and by making facilities and transport available to the group. The "resources" include all tiers of government, large and small enterprises and other welfare organisations. The volunteers were individuals who became involved on a more continuous basis by donating a part of their time to the project or service without expecting to make a financial profit from it. The fourth category mainly encompassed the formal and informal leaders from within the target community who had a direct influence on the success or failure of the project/service (Lansberry, Litwin, Slotnik \& Vaughn, 1995:17-18; Weyers \& Van den Berg, 2006:181, 183, 185).

As far is the input of supporters is concerned, it was clear from the analysis of the articles that successful community social workers were in the habit of getting and keeping as many as possible (appropriate) supporters involved in their projects/services.

- In the case of the support community and resources, it was primarily dependent on their networking skills and ability to:

- establish personal contacts and good relationships with the members of the support community/resources;

- $\quad$ bring them together and put them in touch with each other and with other resources;

- successfully market the project/service's underlying philosophy or vision (e.g. the advancement of "self-help") and benefits to "outsiders";

- give continuous feedback to donors/supporters on the spending of financial and other resources and the results achieved;

- give substantive acknowledgement to contributors in the media or by means of some or other form of reward or recognition system (Badenhorst \& Du Preez, 2004:120; Gray \& Collett van Rooyen, 2002:196; Green \& Nieman, 2003:164, 167, 176-177; Lombard, 2005:218-219; Lombard \& Modise, 2002:7; Naudé \& Terblanche, 2004:156; Weyers \& Van den Berg, 2006:179-183).

- In the case of volunteers, it was primarily dependent on their ability to:

- recruit, train, evaluate, mentor and supervise volunteers;

- formulate a "job description" for each volunteer (i.e. a profile of their role in the organisation/service and the expectations to which they must adhere);

- tap into and utilise the motivators that made them become volunteers (e.g. altruism, sociability, self-interest, use of spare time, reciprocity) by running a reward and recognition system (i.e. giving recognition to work well done, providing incentives to remain involved and generally making them feel valued) (Gathiram, 2003:45; Kruger \& Schreuder, 1999:333; Lombard \& Modise, 2002:2-4, 6-8).

- In the case of formal and informal leaders, it is basically dependent on their ability to convince the leaders to support and keep on supporting the project/service by:

- endorsing it;

- motivating potential project members to become and to remain involved;

- giving the group access to key resources within the community; 
- protecting it from negative influences such as politically motivated interference (and also not trying to "highjack" the project themselves);

- generally contributing to the target community's acceptance of general ownership of the project/service (Gathiram, 2003:45; Lansberry et al., 1995:17-18, Raniga \& Simpson, 2002:187; Weyers \& Van den Berg, 2006:181, 183).

The analysis of the articles indicated that the involvement of supporters did not only contribute to the success of the project on a practical and procedural level. It was also viewed by the project members as a form of moral support and motivated them to persevere often under difficult circumstances.

\section{Habit 3: Be the best you can}

The knowledge, attitudes and skills of community social workers were some of the more "popular" issues that were addressed in the articles. There was a large degree of consensus that each practitioner should have thorough knowledge of community work/developmental social work theory, of the nature and functioning of the target community, and of available support mechanisms within and outside the target community. Expertise regarding the issues being addressed (e.g. HIV/AIDS, the production of goods and child rearing) did not seem to be a prerequisite for success, mainly because experts in these fields could be mobilised to deliver support services to the project (Weyers \& Van den Berg, 2006:184).

A habit that set effective community social workers apart was their desire to continually improve themselves, to improve the quality and appropriateness of their services and to learn from their successes and failures. This habit enabled them:

- to reach out to others, to engender enthusiasm and to motivate people to become and remain involved;

- to be patient during the often slow and time-consuming community work process;

- to come across as "real" people with whom clients could identify;

- $\quad$ to treat the community and its members with respect;

- to view the community as partners and themselves as facilitators;

- to live with the ambiguity, unpredictability, uncertainty and irony that are often part of their work;

- to communicate information, ideas, experiences, hopes, fears, experiences, values, trust, respect and "emotional" support clearly and openly;

- to use communication as a mechanism to build bridges between themselves and others, to create and sustain dialogue, to conscientise all potential role-players and to create a climate in which resources and knowledge could be tapped without fear of being judged (Gray \& Collett van Rooyen, 2002:196; Gumbi, 2002:131; Mavalela et al., 2002:49-50, 62-63; Mkhwanazi \& Triegaardt, 2003:56; Simpson, 2003:158-159; Van der Berg et al., 1999:113114; Weyers \& Van den Berg, 2006:184).

In the "battle" between aptitude and attitude, it would seem as though the latter is a stronger determinant of success. 


\section{FOCUS AREA 2: PROCESSES AND PROCEDURES}

Because of its scientific and professional nature, all community social work services should follow the basic scientific process and be managed in a professional manner. From the practitioners it requires, inter alia, thorough knowledge of the nature of service delivery, the consumer systems' needs and assets, and the ability to do sound planning and administration. As in the case of the other habits, it would seem as though proficiency and efficiency at these tasks are not the main determinants of success, but rather the way in which they are performed.

\section{Habit 4: Activate the push of discomfort and the pull of hope}

In some of the articles that were analysed there was the tendency to view the needs and assets assessment as a technical task. It would, therefore, require some type of research to ensure that the needs are clearly identified and some social engineering to ensure that sufficient assets from within and outside the target community are mobilised to meet their needs, to build the required infrastructure or to provide access to a variety of social services. The ability to perform these tasks should be seen as a basic or generic requirement that all community social workers should meet. The effective practitioners, however, are the ones that are also in the habit of utilising the needs/assets assessment process as a mechanism to activate the push of discomfort and the pull of hope in the community (Sheafor et al., 1997:129). This is most often done by:

- accepting that the community members are experts on their own situation;

- always starting with the community's felt and expressed needs and not shying away if these are essentially material in nature (the prospect of fulfilling ones material needs is a strong pull-factor, especially at the beginning of a project/service);

- utilising collaborative needs assessment methodology/procedures in such a way that this would not only provide data on the nature of the needs (and the accompanying discomfort), but would also conscientise all the role-players with respect to their potential role in the needs-fulfilment process and their ability (power) to do something constructive about it (conscientisation can be viewed as a prerequisite for the development of the will to change or be changed and to become involved in any endeavour);

- putting the community's needs first and not accepting the needs "ascribed" to it by government or organisational policies and or by practitioner bias;

- helping all the role-players to take ownership of both the needs/problems and their fulfilment/solutions;

- not seeing the community as only a reservoir of unfulfilled needs and unsolved problems, but rather as a pool of assets, strengths and abilities that is just waiting to be tapped (Gathiram, 2003:44, 46; Gray \& Collett van Rooyen, 2002:196; Gumbi, 2002:128; Lombard, 2005:219; Nel \& Roestenburg, 2004:122; Raniga \& Simpson, 2002:189; Reyneke, 2004:125; Simpson, 2003:158; Swart, 2005:324-326, 332-333; Van den Berg \& Weyers, 2004:348-349, 361; Weyers \& Van den Berg, 2006:183).

\section{Habit 5: Use management and planning as empowerment tools}

The analysis of the articles brought a long list of required management and planning skills to the fore. It included the ability to do project, financial, administrative, marketing and material management and all the associated planning, organising, coordinating and control elements (Badenhorst \& Du Preez, 2004:115-116). There were, however, also strong indications that project members did not always expect the community social worker to be a manager, bookkeeper or 
leader, but rather a facilitator, coordinator and consultant (Badenhorst \& Du Preez, 2004:119). From these and other trends it first became apparent that effective community social workers were those who were able to plan and manage their own work effectively, but allowed their role in project management to be determined by the expectations and abilities of the project members. Secondly, it was clear that they were also in the habit of utilising the issues and problems that arose from and during management and planning as an empowerment tool. They would, for example:

- $\quad$ use planning and management meetings as a vehicle:

- to teach project members leadership and administrative skills that can also be used outside the narrow ambit of a given project (e.g. skills in participatory planning and management, team-building, consensus decision-making, delegation, strategic thinking, financial management and in providing oral and written feedback);

- to deal with the inevitable conflict that arises between members;

- to use their conflict and power struggles as a learning experience in assertiveness and conflict management;

- to foster trust between members.

- focus on the development of a positive vision of the future and for their involvement in the project;

- let the members experience the "sweet smell of success" by tackling easy-to-achieve goals first, having clear short-term and long-term goals that are in line with the groups' innate abilities to reach them and keeping projects as small and manageable as possible;

- make sure that each member has a "job description" (i.e. a clear understanding of what is expected from them) and experience "job satisfaction" (e.g. by running a reward system) (Badenhorst \& Du Preez, 2004:115-121; Mavalela et al., 2002:63; Nel, 2003:140-141; Weyers \& Van den Berg, 2006:183-184).

\section{FOCUS AREA 3: THE CONSUMER SYSTEM}

In the research the concept "consumer system" was used in a narrower sense to include only those individuals who gained a direct benefit from the service (Weyers, 2001:68). They are usually referred to as the "project members" or "community group". The articles contained a large number of changes that the community social worker could or should bring about in the consumer system's knowledge, attitude and behaviour. From the analysis it, however, emerged that the biggest determinate of success was the extent to which the project members/community group developed an internal locus of control.

\section{Habit 6: Instil an internal locus of control in your project members/community group}

Because a community work/developmental social work service represents a collaborative effort between the practitioner, a community group and other role-players, it is inevitable that any deficiencies in one of these systems would have a negative effect on goal attainment. Ultimate success is especially dependent on a motivated community group or corps of project members. Motivation (i.e. the desire for change) and its concomitant commitment to break deeply imbedded habitual tendencies (Covey, 1989:46) is not an innate trait of the consumer system, but rather something that should be actively sought or engendered. It was, therefore, not surprising that the 
analysed articles showed that the most salient characteristic of effective community social workers was their ability to motivate and inspire project members.

The articles showed that, at the most basic level, project members will develop a desire for change if they can be convinced that they will be substantially better-off after their endeavours than they were beforehand. The factors that constituted being "substantially better-off" differed widely from one practice situation to the next. It covered the whole range of Maslow's hierarchy of needs (Kotler \& Armstrong, 2001:187) and included:

- material and infrastructural benefits (e.g. gaining money, food and a specific type of facility or service or being provided with access to resources);

- $\quad$ social benefits (e.g. positive interpersonal relationships and support and a sense of belonging, trust and respect);

- self-esteem benefits (e.g. increased self-confidence, self-reliance and resiliency, enhanced feelings of self-respect and being deserving of other people's respect and public recognition of their contribution and achievements);

- self-actualisation benefits (e.g. the acquisition of a wide variety of skills including income generation, leadership, administration, problem-solving, assertiveness and networking skills, and feelings that they are personally "making a difference" in somebody's life) (Green \& Nieman, 2003:164, 167; Lombard, 2003:232, 237-238; Reyneke, 2004:125, 135; Simpson, 2003:149, 157).

If it is accepted that the desire to fulfil needs is a strong motivator in human behaviour (Kotler \& Armstrong, 2001:186), it would be possible for the practitioner to use Maslow's theory of motivation and associated hierarchy of needs as a "checklist" of the needs to focus on in order to motivate his/her particular project members. It would also imply that it would be a demotivator if, for example, a project dealt only with self-actualisation needs while physiological or safety needs have not yet been sufficiently met.

The effectiveness of community social workers, however, was not primarily determined by their ability to address individual needs. It was rather dependent on their habit of instilling an internal locus of control in their project members. This is often achieved by helping them:

- to unlearn their learned helplessness mindset by, for example:

- making them aware of the negative outcomes of some of their current behaviour patterns (i.e. practices and procedures), traditions and values;

- using all means possible to convince them not only to take ownership of their current situation but also of the ways and means to bring changes to it.

- not to see themselves and/or their community as victims but rather as potential victors by, for example:

- convincing them that they are people of innate worth that deserve better;

- developing an individual and shared positive and clear vision of what they want to achieve in the future;

- convincing them that groups have more inherent power than individuals and that it is, therefore, one of the "best" mechanisms through which victory can be achieved (Gathiram, 2003:44-45; Gray \& Collett van Rooyen, 2002:196; Green \& Kruger, 
2002:253-255; Green \& Nieman, 2003:162-164, 167, 176-177; Gumbi, 2002:128; Lombard, 2003:232, 237-238; Lombard, 2005:218; Mavalela et al., 2002:49, 63; Raniga \& Simpson, 2002:182, 187-188; Reyneke, 2004:125, 135; Simpson, 2003:149, 157; Weyers \& Van den Berg, 2006:183).

From the content of the analysed articles it was deduced that the ability to instil an internal locus of control in project members is probably the most difficult skill to master in community work/developmental social work services.

\section{FOCUS AREA 4: THE CRITICAL “CROSS-FIELD” HABITS}

The study brought two habits to the fore that did not fit into a single focus area, but rather transcends all three. They were the habits of building partnerships and of self-renewal. Because they determined success in all the other fields, they were designated as the "critical cross-field habits".

\section{Habit 7: Build partnerships}

The habit of building successful partnerships with all the potential role-players was an important habit of successful community social workers. Partnerships were basically the "cement that kept service delivery together" and included the ability to network, build interpersonal relationships, co-operate, co-ordinate, collaborate and/or form coalitions with:

- $\quad$ the project members;

- the employer organisation;

- the community leaders and the target community at large;

- $\quad$ volunteers and experts;

- the broader support community such as the state, the private sector (including funding agencies and the business sector) and the non-government sector (e.g. community-based (CBO), mass-based (MBO) and faith-based (FBO) organisations) (Gray \& Crofts, 2004:247, 254-256; Lombard \& Du Preez, 2004:233; Van den Berg \& Weyers, 2004:362).

\section{Habit 8: Spend time on self-renewal}

The last habit did not, unfortunately, emerge primarily from the analysis of the 24 articles that dealt with community work/developmental social work services. It came rather from ones that dealt with stress, burnout and job (dis-)satisfaction amongst social workers (Clarke-McLeod \& Sela, 2005; Kasiram, 1999; Malherbe \& Hendriks, 2004; Matlhabe, 2001; Narayan, 2005; Ross, 1997). These indicated that, in order to be and to remain effective, practitioners should be in the habit of spending time on self-renewal.

All 24 articles implied that the rendering of community social work services was not easy. It tended to be physically and mentally exhausting, tapped the practitioner's patience (services usually took a long time to bear fruit) and perseverance (they sometimes had to face seemingly insurmountable odds) and often shook their inherent belief in people's ability to break deeply imbedded habitual tendencies. This sometimes led to disillusionment and an inclination to leave community practice or even to quit the profession altogether (Clarke-McLeod \& Sela, 2005:162; Matlhabe, 2001:67-68; Mkhwanazi \& Triegaardt, 2003:56-58).

It should be accepted that, in the final analysis, the practitioner him/herself is the biggest single determinant of the ultimate success or failure of any community social work endeavour. Effective 
practitioners should not only strive to enhance the consumer system's well-being, but must be just as committed to their own personal wellness (Layton \& Collins, 2004:430). Employers should, therefore, provide them with the time and opportunities for self-renewal and they should use these optimally.

The habit of self-renewal can take on a variety of forms. It includes taking time off and using opportunities:

- to reflect on and to rethink their position in the "greater scheme of things" (this can vary from, for example, going to a retreat for a day or more to taking "time-out"/a couple of minutes off for quiet self-reflection, visualisation, self-affirmation, meditation and or "communication" with a "force" greater than themselves);

- to (re-)gain a bird's eye view of the broad context within which they operate (e.g. by becoming active members of professional associations, reading newspapers, watching news and actuality programmes on television, reading the articles in accredited journals that do not only pertain to the narrow ambit of their work, etc. in order to see their endeavours in a broader context and, hopefully, in a new light);

- to sharpen their skills and knowledge (i.e. keeping abreast of developments in their own and associated field and gaining exposure to new ideas and techniques by, for example, attending all available conferences, in-service training, workshops, seminars and other training opportunities and/or by undertaking postgraduate studies);

- to build and maintain support networks (caring and supportive spouses or parents that give practitioners encouragement and recognition, and help with household chores proved to be a strong work stress-reduction mechanism, as were caring and supporting friends, colleagues and religious affiliates. These support networks should, however, not be taken for granted but actively sought and nurtured);

- for self-care (managing their personal lives by, for example, balanced eating, adequate rest, appropriate exercise, taking regular vacations and doing relaxation/stress-management exercises and managing their personal work environment by, for example, time management, self-assertive behaviour and overload avoidance);

- for forgiveness (the ability to forgive oneself for not being able address all the problems/needs all of the time is, according to Kasiram (1999:347), as important for the practitioner as it is for the client system) (Booley, 1997:110; Clarke-McLeod \& Sela, 2005:164-165; Kasiram, 1999:346-349; Layton \& Collins, 2004:430-436; Malherbe \& Hendriks, 2004:28-34; Matlhabe, 2001:67-68; Narayan, 2005:10, 13; Ross, 1997:64-65; Van Zyl \& Botha, 1997:24, 31).

The habit of self-renewal surrounds all the other habits because it is the one that makes all others possible (Covey, 1989:287). Without it, the community social worker will soon lose his/her ability to function as an effective service delivery "instrument" and as an effective individual.

\section{CONCLUSIONS AND RECOMMENDATIONS}

The (somewhat ambitious) aim of the study was to identify the habits that make highly effective community social workers so effective. Because the available articles focused mostly on the requirements that community social workers should meet and paid scant attention to their personality traits and habitual tendencies, the conclusions were far from comprehensive and final. They did, however, contain enough substantiated information to identify at least 8 core habits. It is 
recommended that these habits form the basis of a credo that all community social workers should live by. This credo can be formulated as follows:

- I will gain the moral support of my employer and colleagues (Habit 1);

- I will get and keep all appropriate supporters involved (Habit 2);

- I will use management and planning as empowerment tools (Habit 5);

- I will activate the push of discomfort and the pull of hope in my project members/community group (Habit 4);

- I will instil an internal locus of control in my project members/community group (Habit 6);

- I will build partnerships (Habit 7);

- I will be the best I can (Habit 3);

- I will spend time on self-renewal (Habit 8).

The analysis of the articles in the two journals indicated that, since the publication of the White Paper for Social Welfare, the social work fraternity has come a long way in identifying the more "technical" and procedural elements of effective service delivery. In the past decade a substantial body of knowledge has been developed that could guide practitioners in their endeavours. The "missing link" in these studies has, however, been a lack of data on practitioners as individuals and on the behaviour patterns that they exhibit. In the decade ahead more empirical research should be done on the factors that make community social workers effective. They are, after all, the kingpin in community work/developmental social work as a people-driven process.

\section{REFERENCES}

BADENHORST, M. \& DU PREEZ, M.S.E. 2004. Maatskaplikewerkriglyne vir die fasilitering van gemeenskapsgebaseerde projekbestuur. Maatskaplikewerk-Navorser-Praktisyn/Social Work Researcher-Practitioner, 16(2):113-122.

BOOLEY, S. 1997. The supervisory role in the fostering of critical self-reflection capacity in social workers. Social Work/Maatskaplike Werk, 33(2):110-119.

CLARKE-McLEOD, P.G. \& SELA, M. 2005. Job satisfaction amongst government social workers in East London. Social Work Researcher-Practitioner/Maatskaplikewerk-NavorserPraktisyn, 14(1):48-66.

COVEY, S.R. 1989. The 7 habits of highly effective people. London: Simon \& Schuster.

GATHIRAM, N. 2003. Participation, civil society and social work practice. Social Work/Maatskaplike Werk, 39(1):41-47.

GRAY, M. \& COLLETT VAN ROOYEN, C.A.J. 2002. The strengths perspective in social work: lessons from practice. Social Work/Maatskaplike Werk, 38(3):193-201.

GRAY, M. \& CROFTS, P. 2004. Partnerships: marrying the strengths and resources of diverse interest groups. Social Work/Maatskaplike Werk, 40(3):246-259.

GREEN, S. \& KRUGER, S.P. 2002. Resource and support programmes for poor families in a rural residential area. Social Work/Maatskaplike Werk, 38(3):253-259.

GREEN, S. \& NIEMAN, A. 2003. Social development: good practice guidelines. Social Work/Maatskaplike Werk, 39(2):161-181. 
GUMBI, T.A.P. 2002. Community development, participation and empowerment: conditions for rural development in South Africa. Social Work Researcher-Practitioner/MaatskaplikewerkNavorser-Praktisyn, 14(3):114-135.

KASIRAM, M.I. 1999. Healing the healer. Social Work/Maatskaplike Werk, 35(4):344-350.

KOTLER, P. \& ARMSTRONG, G. 2001. Principles of marketing ( $9^{\text {th }}$ ed). Upper Saddle River (N.J.): Prentice Hall.

KRUGER, S.P. \& SCHREUDER, M. 1999. The effective utilisation of volunteers. Social Work/Maatskaplike Werk, 35(4):333-342.

LANSBERRY, J., LITWIN, J., SLOTNIK, W. \& VAUGHN, J. 1995. Effective community development. The Journal of Housing and Community Development, 52(1):12-18.

LAYTON, E. \& COLLINS, K. 2004. Advancing through retreating: self-care among helping practitioners. Social Work/Maatskaplike Werk, 40(4):430-445.

LOMBARD, A. 2003. Entrepreneurship in Africa: social work challenges for human, social and economic development. Social Work/Maatskaplike Werk, 39(3):224-239.

LOMBARD, A. 2005. Impact of social services on human, social and economic development and the promotion of human rights in South Africa. Social Work/Maatskaplike Werk, 41(3):209227.

LOMBARD, A. \& DU PREEZ, J. 2004. Challenges for building partnerships in social development. Social Work/Maatskaplike Werk, 40(3):232-245.

LOMBARD, A. \& MODISE, V.M. 2002. Retaining volunteers in African communities with specific reference to the Cancer Association of South Africa. Social Work/Maatskaplike Werk, 38(1):1-14.

MALHERBE, B.R. \& HENDRIKS, E. 2004. An investigation into the determinants of job satisfaction and the improvement of quality of work life of grassroots social workers. Social Work/Maatskaplike Werk, 40(1):25-42.

MATLHABE, D. 2001. The transition to work: professional social workers in their first year of practice. Social Work/Maatskaplike Werk, 37(1):59-71.

MAVALELA, H.R., SCHENCK, R \& O’NEIL, M. 2002. The story of "Phela O Phedise" incomegenerating project. Social Work Researcher-Practitioner/Maatskaplikewerk-NavorserPraktisyn, 14(1):48-66.

MKHWANAZI, H.F. \& TRIEGAARDT, J. 2003. Reconceptualisation of social work: a study in Johannesburg. Social Work Researcher-Practitioner/Maatskaplikewerk-Navorser-Praktisyn, 15(1):48-60.

NARAYAN, G.S. 2005. Social workers in management: work/family stress and issues of selfcare. Social Work/Maatskaplike Werk, 41(1):1-16.

NAUDÉ, C. \& TERBLANCHE, L.S. 2004. Die ontwikkeling van ' $n$ bemarkingstrategie vir Centurion Gemeenskapsdiens. Maatskaplike Werk/Social Work, 40(2):139-157.

NEL, H. \& ROESTENBURG, W. 2004. Assessment of a community: promoting an equitable society through inclusion and empowerment. Social Work/Maatskaplike Werk, 40(2):113-123.

NEL, J.B.S. 2003. A Soweto community leadership training programme: lessons out of Africa. Social Work Researcher-Practitioner/Maatskaplikewerk-Navorser-Praktisyn, 15(2):128-144. 
POGGENPOEL, M. 1998. Data analysis in qualitative research. In: DE VOS, A.S. (ed) Research at grass roots: a primer for the caring professions. Pretoria: Van Schaik Publishers: 334-353.

RANIGA, T. \& SIMPSON, B. 2002. Community participation: rhetoric or reality? Social Work/Maatskaplike Werk, 38(2):182-191.

REYNEKE, R.P. 2004. Die benutting van narratiewe beginsels tydens gemeenskapsontwikkeling. Social Work/Maatskaplike Werk, 40(2):125-138.

ROSS, E. 1997. Family life and work stress among South African social workers. Social Work/Maatskaplike Werk, 33(1):52-68.

SCHENCK, C.J. 2004. Problems rural social workers experience. Social Work/Maatskaplike Werk, 40(2):158-171.

SHEAFOR, B.W., HOREJSI, C.R. \& HOREJSI, C.A. 1997. Techniques and guidelines for social work practice. Boston: Allyn and Bacon.

SIMPSON, B. 2003. What do residents of informal settlements think social workers should do: voices from Bhambayi. Social Work/Maatskaplike Werk, 39(2):149-160.

SOUTH AFRICA (REP.), DEPARTMENT OF WELFARE. 1997. White paper for Social Welfare: Principles, guidelines, recommendations, proposed policies and programmes for developmental social work in South Africa. Pretoria: Government Printer. (ISBN 0-621-175811)

STRYDOM, H. \& DELPORT, C.S.L. 2005. Information collection: document study and secondary analysis. In: DE VOS, A.S. (ed) Research at grass roots for the social sciences and human service professions. Pretoria: Van Schaik Publishers: 314-326.

SWART, I. 2005. Mobilising faith-based organisations for social development through a participatory action research (PAR) process. Social Work/Maatskaplike Werk, 41(4):323-336.

VAN DEN BERG, A.M. \& WEYERS, M.L. 2004. Die gemeenskapswerkdienste van die private welsynsektor: 'n profiel met implikasies. Maatskaplike Werk/Social Work, 40(4):344-365.

VAN DER BERG, C., COLLINS, K. \& O’NEIL, M.A. 1999. Die gemeenskapswerker en taalkonstruktivisme in die fase van behoeftebepaling. Maatskaplike Werk/Social Work, 35(2):113-123.

VAN ZYL, R. \& BOTHA, N.J. 1997. The professional development of social workers. Social Work/Maatskaplike Werk, 33(1):24-35.

WEYERS, M.L. 2001. The theory and practice of community work: a South African perspective. Potchefstroom: Keurkopie.

WEYERS, M.L. \& VAN DEN BERG, A.M. 2006. The success factors in community work services: a critical incident study. International Social Work, 49(2):177-187.

WHITE PAPER FOR SOCIAL WELFARE see SOUTH AFRICA (REP.), DEPARTMENT OF WELFARE. 1997.

Prof Mike Weyers, School for Psychosocial Behavioural Sciences: Social Work Division, North-West University: Potchefstroom Campus, South Africa. 